\title{
Hypohidrotic ectodermal dysplasia - a case report
}

\author{
Svetlana POPADIĆ ${ }^{1,2}$, Andreja VUJANAC ${ }^{1}$, Biljana ARSOV ${ }^{1}$, \\ Petar IVANOVSKI ${ }^{3}$, Miloš NIKOLIĆ ${ }^{1,2, *}$ \\ ${ }^{1}$ Pediatric Dermatology Unit, Clinic of Dermatovenereology, Clinical Center of Serbia, Belgrade, Serbia \\ ${ }^{2}$ Faculty of Medicine, University of Belgrade, Republic of Serbia \\ ${ }^{3}$ University Childrens Hospital, Belgrade, Republic of Serbia \\ ${ }^{*}$ Correspondence: Miloš Nikolić, E-mail: milos.nikolic@med.bg.ac.rs
}

UDC 616.53/.596-056.7

VERSITA

\begin{abstract}
Ectodermal dysplasias are a large group of disorders characterized by developmental dystrophies of one or more ectodermal structures. Hypohidrotic ectodermal dysplasia is a rare genodermatosis associated with abnormal development of sweat glands, teeth, and hair. Its incidence is 1:100.000 newborns. The full expression of X-recessive forms are only seen in males, while female heterozygotes are moderately or very slightly affected. The disease is characterized by sparse hair, oligodontia, and reduced or absent sweeting, light hair, distinctive facial features, palmoplantar keratoderma.

We report an 11-year-old boy with hypohidrotic ectodermal dysplasia. Despite extensive skin, teeth and hair manifestations, his physical and psychomotor growth and development were normal.
\end{abstract}

\section{Key words}

Ectodermal Dysplasia, Hypohidrotic, Autosomal Recessive; Child; Skin Diseases, Genetic; Signs and Symptoms

$\mathrm{E}$ ctodermal dysplasias (ED) are inherited disorders involving the skin, teeth, hair and nails. Hypohidrotic ectodermal dysplasia (HED) or anhidrotic ectodermal dysplasia (Christ-SiemensTouraine syndrome) is the most common form of ED. HED was first described by Wedderburn in 1838, and later by Thurnam, in 1848 (1-3).

HED is mainly inherited as an X-linked recessive disorder and the syndrome is fully expressed only in males. Female carriers may show mild features of the syndrome $(4,5)$. The syndrome is characterized by absence of sweating with hyperpyrexia, hypotrichosis and teeth abnormalities (hypodontia or anodontia). The affected individuals have dry skin, sparse and thin scalp hair, while eyebrows may be sparse or totally absent (1-3).

\section{Case report}

An 11-year-old boy was admitted to the Pediatric Dermatology Unit, Clinic of Dermatovenereology, Clinical Center of Serbia, with clinical features suggestive of HED. He had dry and sensitive skin since birth. On presentation, his scalp hair and eyelashes were sparse and hypopigmented, the eyebrows were absent and he had marked dark eyelid erythema (Figures 1 and 2). The skin was dry, scaly, lichenified and excoriated. His palms were hyperlinear (Figure 3) with slight nail dystrophy. The nasal bridge was depressed, consistent with a "saddle nose" (Figure 4). Mandibular teeth were absent, while he had maxillar hypodontia with typical conical incisors (Figure 5) and perioral erythema. Further pediatric examination was normal. Routine blood and urine laboratory tests were normal. 


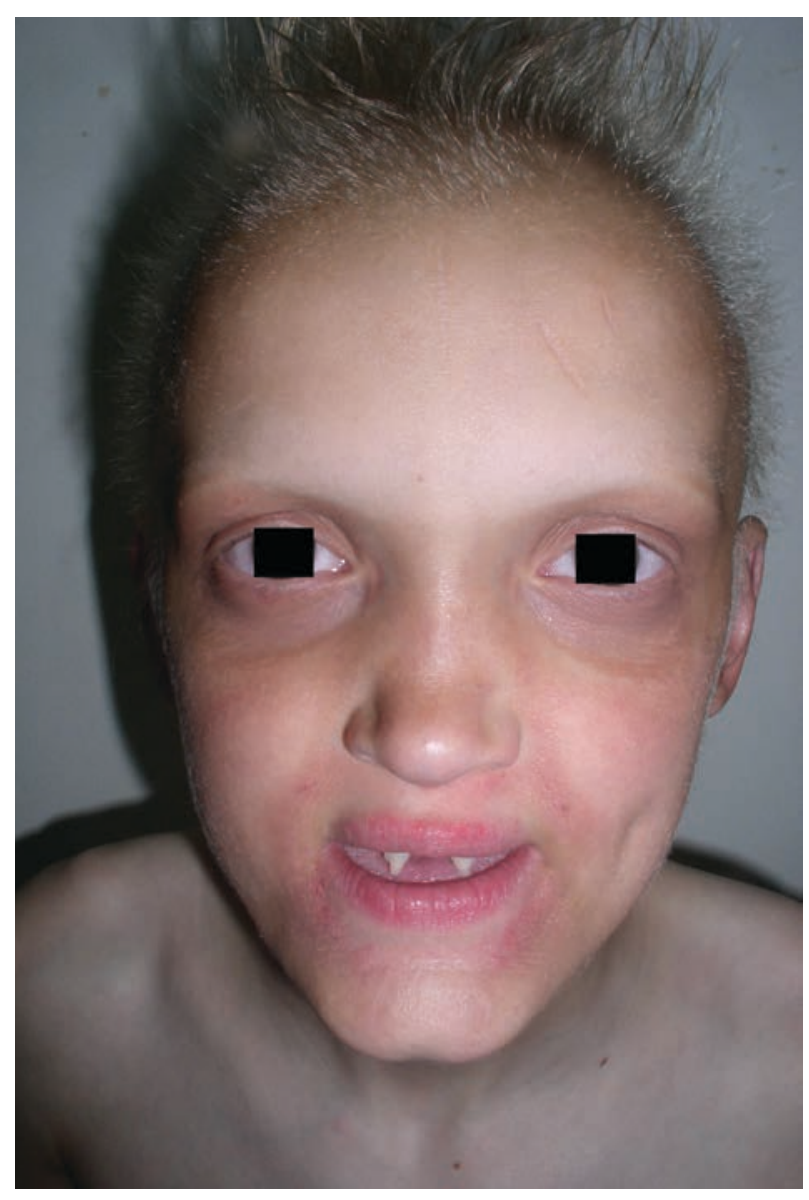

Figure 1. Sparse and hypopigmented hair and eyelashes, absent eyebrows and dark eyelid erythema

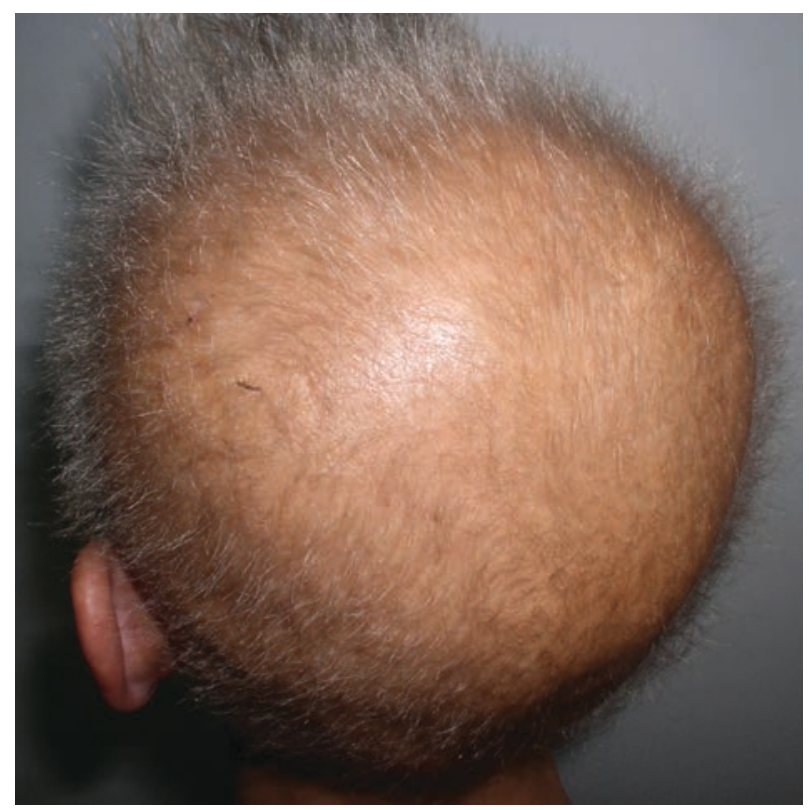

Figure 2. Sparse and hypopigmented hair

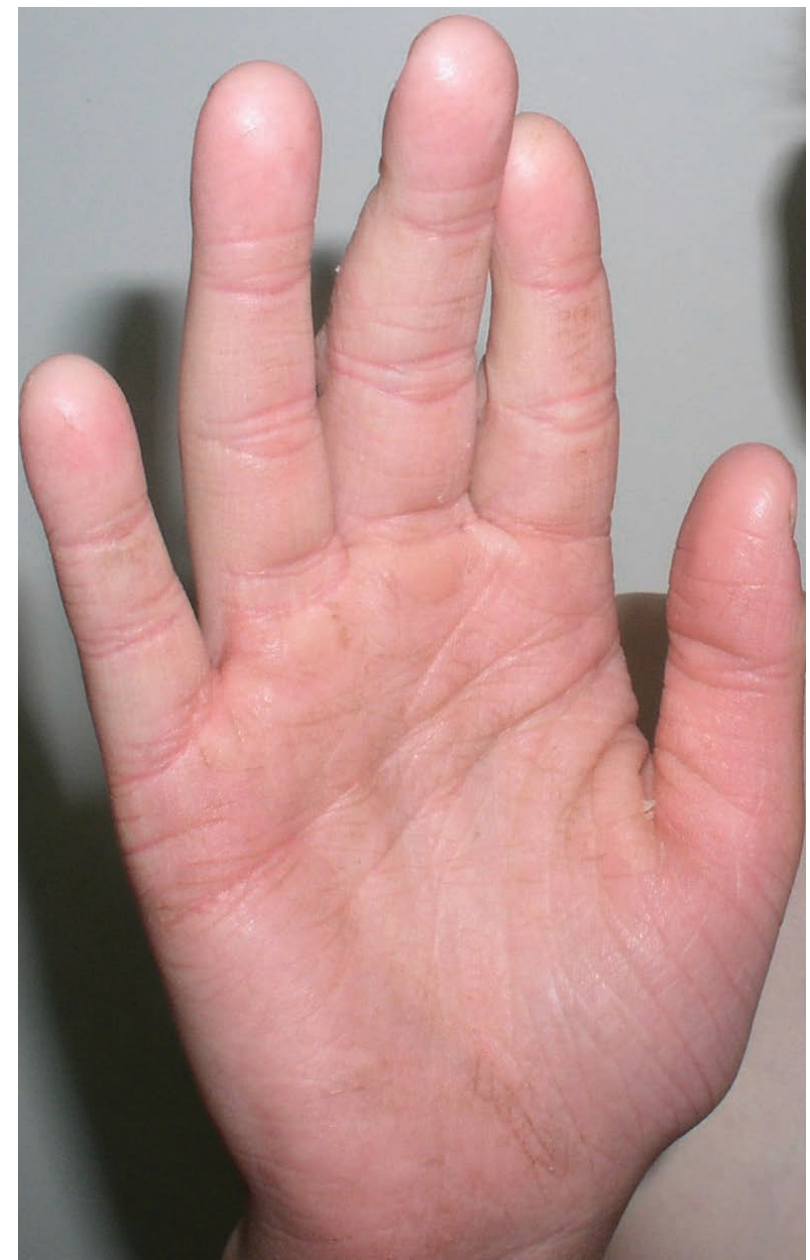

Figure 3. Marked palmar hyperlinearity

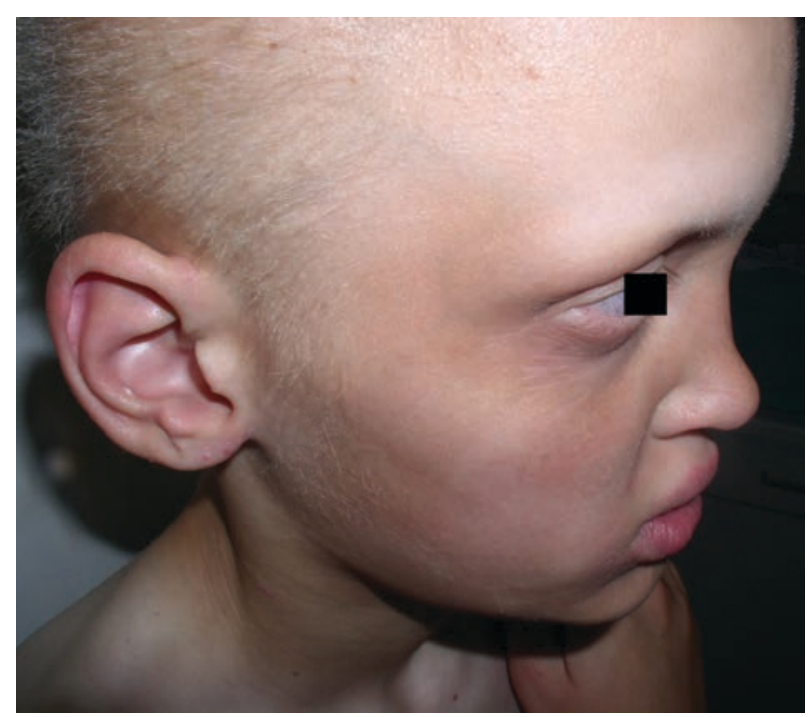

Figure 4. Depressed nasal bridge, thick everted lips, absent eyebrows, dark and wrinkled periorbital skin

(C) 2009 The Serbian Association of Dermatovenereologists 


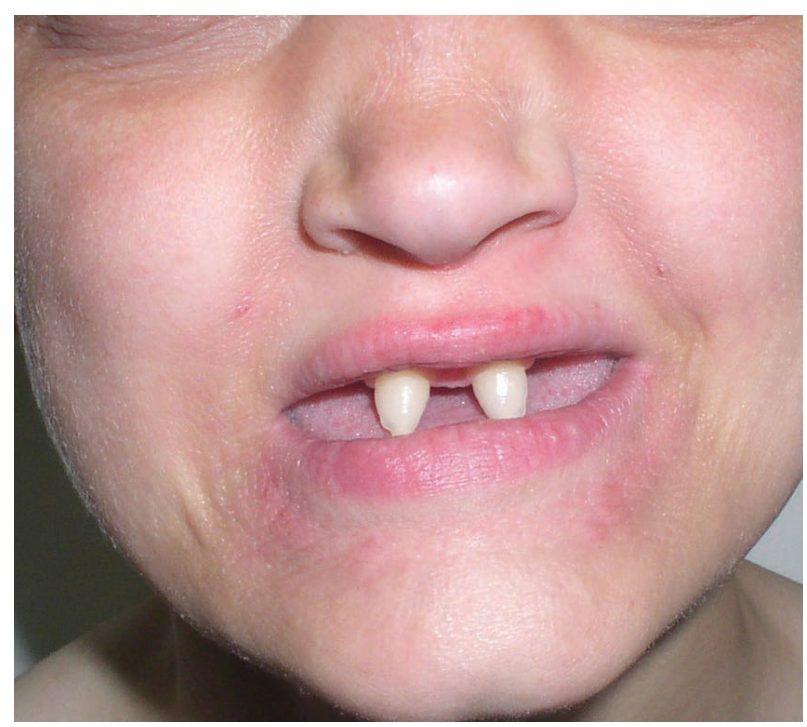

Figure 5. Maxillary hypodontia with typical conical incisors and perioral erythema

The patient's personal history showed one episode of bronchopneumonia during childhood, and congenital hypospadia, for which he underwent surgical correction immediately after birth. The patient also showed physical effort intolerance, reduced sweating and dry and itchy skin. Dentition was delayed, and the first teeth appeared by the end of the first year of life. In family history, the boy's mother suffered from chronic hand eczema.

The treatment included bland emollients and topical glucocorticosteroids for erythematous areas.

\section{Discussion}

Hypohidrotic ectodermal dysplasia is a congenital, non-progressive disorder characterized by hypodontia, hypohidrosis and hypotrichosis (1-3). It is inherited in an autosomal dominant, autosomal recessive, or $\mathrm{X}$-linked patterns $(4,5)$. The diagnosis is established by genetic tests or, after infancy, based on physical features. In some patients, the pattern of inheritance is determined by family history, and in others by molecular genetic testing. Also, genetic carrier testing is performed in X-linked and autosomal recessive forms. Ninety-five percent of randomly selected individuals have the X-linked form of $\operatorname{HED}(4,5)$.

Three disease-causing genes have been indetified: ectodysplasin A1 (EDA1) gene, accounting for $\mathrm{X}$-linked forms, ectodysplasin A1 receptor (EDAR) gene, and ectodysplasin A1 receptor associated death domain (EDARADD), causing both autosomal dominant and recessive forms $(4,5)$. The EDA1, EDAR, and EDARADD genes provide instructions for making proteins that work together during embryonic development. These proteins form part of the signaling pathway that is critical for the interaction between two cell layers, the ectoderm and the mesoderm. In the early embryo, these cell layers form the basis for many of the body's organs and tissues. Ectoderm-mesoderm interactions are essential for the formation of several structures that arise from the ectoderm, including the skin, hair, nails, teeth, and sweat glands $(4,5)$.

In the neonatal period patients may have dry, scaly skin with periorbital hyperpigmentation. During infancy, the skin may be dry and sensitive, with pronounced heat intolerance $(3,6)$. The diagnosis is often delayed until the teeth fail to erupt at the proper time (6-9 months), or the teeth that erupt are conical in shape. Also, by this age, affected individuals may present with chronic eczema and wrinkled periorbital skin $(1,6)$.

In our patient, skin manifestations were present in the early neonatal period, including scaly and slightly erythematous skin. During infancy, he developed other characteristic manifestations of HED. Dentition was delayed and irregular. His physical and psychomotor development was otherwise normal. Topical bland emollients were recommended, as well as regular dental care and avoiding extreme physical efforts in order to prevent hyperthermia.

\section{Conclusion}

Hypohidrotic ectodermal dysplasia is the most common form of ectodermal dysplasias. Patients suffering from hypohidrotic ectodermal dysplasia should be carefully monitored by dermatologists, to provide the best possible skin care agents, and by dentists, in order to prevent caries development and provide interventions if necessary. Patients and parents should be instructed to avoid extreme heat exposure, because of possible problems associated with heat intolerance.

\section{Abbreviations}

ED - Ectodermal dysplasias

HED - Hypohidrotic ectodermal dysplasia

EDA1 - Ectodysplasin A1 
EDAR - Ectodysplasin A1 receptor

EDARADD - Ectodysplasin A1 receptor associated death domain

\section{References}

1. Champlin TL, Mallory SB. Hypohidrotic ectodermal dysplasia: a review. J Ark Med Soc 1989;86(3):115-7.

2. Tape MW, Tye E. Ectodermal dysplasia: literature review and a case report. Compend Contin Educ Dent 1995;16(5):524-8.
3. Dunn WJ. Hypohidrotic ectodermal dysplasia: a review and case report. Gen Dent 2003;51(4):346-8.

4. Cluzeau C, Hadj-Rabia S, Jambou M, Mansour S, Guigue P, Masmoudi S, et al. Only four genes (EDA1, EDAR, EDARADD, and WNT10A) account for $90 \%$ of hypohidrotic/anhidrotic ectodermal dysplasia cases. Hum Mutat 2011;32:70-7.

5. Mikkola ML. Molecular aspects of hypohidrotic ectodermal dysplasia. Am J Med Genet A 2009;149A(9):2031-6.

6. Kupietzky A, Houpt M. Hypohidrotic ectodermal dysplasia: characteristics and treatment. Quintessence Int 1995;26(4):285-91.

\section{Hipohidrotska ektodermalna displazija - prikaz slučaja}

\section{Sažetak}

Uvod: Ektodermalne displazije predstavljaju veliku heterogenu grupu naslednih oboljenja kod kojih postoje lezije dva ili više tkiva poreklom iz embrionalnog ektoderma. Nesleđuju se X-vezano recesivno, autozomno dominantno ili autozomno recesivno. Najčešće su zahvaćeni zubi, kosa, ekrine žlezde i nokti. Hipohidrotska ektodermalna displazija - Krist -Simens-Tuarenov sindrom (Christ-SiemensTouraine) najčešća je forma i čini $80 \%$ svih slučajeva ektodermalne displazije.

Prikaz slučaja: Prikazujemo pacijenta, uzrasta 11 godina, koji od rođenja ima suvu kožu i proređenu depigmentovanu dlaku na kapilicijumu. Pri prijemu, koža kapilicijuma, lica, trupa i ekstremiteta bila je u celini suva, sa nejasno ograničenim eritemom i hiperpigmentacijama periokularno, minimalno infiltrovanim bledoeritematoznim lihenihikovanim plakovima na bočnim stranama vrata i fleksurama. Obostrano palmarno i plantarno izražena je hiperkeratoza, hiperlinearnost dlanova, distrofične nokatne ploče. Supercilije u potpunosti nedostaju, cilije proređene, izražena je hipodoncija sa dva klinasto oblikovana zuba na maksili.

Lečenje: Započeta je terapija kortikosteroidnim preparatima za lokalnu primenu i emolijentnim sredstvima. Rutinske laboratorijske analize i pedijatrijski nalaz bili su uredni. Po otpustu, savetovana je upotreba emolijentnih kremova sa preporukom za negu i izbegavanje ekstremnih fizičkih napora. Pacijentu i roditeljima je objašnjen rizik od hiperpireksije.

Zaključak: Hipohidrotsku ektodermalnu displaziju prvi put je opisao Ternam (Thurnam) 1848. godine. Incidencija je 1:100.000 neonatusa. Puna ekspresija X-recesivne forme viđa se samo u muškaraca, dok su ženski heterozigoti umereno ili sasvim slabo aficirani. I pored ekstenzivnih promena na koži, zubima i kožnim adneksima, fizički i psihomotorni rast i razvoj su u fiziološkim granicama za uzrast.

\section{Ključne reči}

Hipohidrotska autozomalna recesivna ektodermalna displazija; Dete; Genetske bolesti kože; Znaci i simptomi 